\title{
Assessment of Selected Trace Elements in Fruits and Vegetables Cultivated Around Mojo, Meki and Zeway Irrigation Farms, Ethiopia
}

\begin{abstract}
Aschalew Tadesse Marga
(M.Sc. Analytical Chemistry), Adama Science and Technology University, School of Applied Natural Science, Applied Chemistry Program

Abstract: This study was conducted to analyze the heavy metals in selected fruit and vegetables produced in irrigation farms around Mojo, Meki and Zeway area, Ethiopia. The total 8 samples viz., 4 vegetables and 4 fruits were collected which are commonly produced in the areas. These were digested using dry ashing method assisted with concentrated nitric acid and the ash dissolved with $3 N$ hydrochloric acid and analyzed with the aid of Parkin - Elmer Atomic Absorption Spectrometer to determine the level of heavy metals (Lead, Cadmium, Copper, Zinc, Cobalt and Nickel). The results obtained were compared with their permissible levels set by the FAO and WHO and were found to be within safe limits for all analyzed heavy metals.
\end{abstract}

Keywords: Heavy metals, lead, cadmium, copper, cobalt, nickel, dry ashing, permissible levels, fruit, vegetables

\section{Introduction}

The risk of heavy metal contaminated fruit and vegetables cannot be underestimated as these foodstuffs are important components of human diet. Fruit and vegetables are rich sources of vitamins, minerals, and fibers and also have significant antioxidative effects [1]. However, the intake of heavy metal-contaminated fruit and vegetables may pose a risk to human health; hence the heavy metal contamination of food is one of the most important aspects of food quality assurance [2, 3]. Heavy metals are not biodegradable, have long biological half-lives and the potential for accumulation in different body organs, leading to unwanted side effects [4 - 7]. Plants take up heavy metals by absorbing them from airborne deposits on the parts of the plants exposed to the air from the polluted environments as well as from contaminated soils and water through root systems [8 - 11].

Researchers have investigated the concentrations of some heavy metals (lead, cadmium, copper, and zinc) in different vegetables grown in various parts of world [12 - 15]. Based on their persistence and cumulative behavior as well as the probability of potential toxicity effects, the absorption of heavy metals in human diets as a result of the consumption of vegetables and fruits suggest that there is a requirement for the analysis of food items to ensure that the levels of trace heavy metals meet the agreed international standards. This is particularly important for farm products from parts of the world where only limited data on the heavy metal content are available. Information on the contamination of fruit and vegetables with heavy metals from the Irrigation farms in Rift valley region (Mojo, Meki and Zeway region) of Ethiopia has not yet been established. Therefore, the present study was carried out with the aim to compare and investigate the level of some selected heavy metals $(\mathrm{Pb}, \mathrm{Cd}$, $\mathrm{Zn}, \mathrm{Cu}, \mathrm{Co}$, and $\mathrm{Ni}$ ) found in some selected fruit and vegetables from this region.

\section{Material and Methods}

Sample Collection: A total of 200 samples of fruit and vegetable produced were purchased from several irrigation farms around Mojo, Meki and Zeway area, Ethiopia, during 2014. The sampling comprised $1.5 \mathrm{~kg}$ for each commodity and was considered to be quite representative; for the analysis, only the edible portions of each fruit and vegetable were included, and additionally the bruised or rotten parts were removed.

Sample Pre-treatment and Preparation: Subsamples (each of $0.5 \mathrm{~kg}$ ) were taken at random from the composite sample and were processed for analysis by the dry ashing method. The samples were first oven dried at $105^{\circ} \mathrm{C}$ for $24 \mathrm{~h}$. The dried samples were then powdered using grinder. $14 \mathrm{~g}$ of powdered samples was taken in three replicates for each food item, and few drops of concentrated nitric acid were added to the solid as an aid to ashing. The dry ashing process was carried out in muffle furnace by stepwise increase of the temperature up to $550^{\circ} \mathrm{C}$ and the samples left to ash at this temperature for $6 \mathrm{~h} \mathrm{[16].} \mathrm{The} \mathrm{ash} \mathrm{was} \mathrm{dissolved}$ with $3 \mathrm{~N}$ hydrochloric acid transferred into $50 \mathrm{~mL}$ volumetric flask by filtering through Whatman No. 1 filter paper, and the volume was made up to the mark with $3 \mathrm{~N}$ hydrochloric acid.

Standards: Stock standard solutions (1000 mg/L standards in $0.1 \mathrm{~N} \mathrm{HNO}_{3}$ ) of the heavy metals( lead (Pb), cadmium (Cd), copper $(\mathrm{Cu})$, cobalt $(\mathrm{Co})$, nickel $(\mathrm{Ni})$, and zinc $(\mathrm{Zn}))$ were provided by Merck (Darmstadt, Germany). A series of working standards were prepared from these standard stock solutions.

Quality Assurance: Appropriate quality assurance procedures were taken to ensure the reliability of the results. Samples were carefully handled to avoid cross contamination. Glassware was properly cleaned using 3N hydrochloric acid and deionized water, and reagents used were of analytical grades. Reagent blank determinations were done for corrections to the instrument readings. For validation of the analytical procedure, repeated analyses of the samples against certified sugar standard reference material (SRM) were used, and the results were found to lie within \pm 0.01 of the certified values. 


\section{International Journal of Science and Research (IJSR) \\ ISSN (Online): 2319-7064 \\ Index Copernicus Value (2013): 6.14 | Impact Factor (2015): 6.391}

Daily Intake of Heavy Metals through Fruits and Vegetables: The daily intake of heavy metals through the consumption of fruit and vegetables tested was calculated according to the equation $[17,18]$ :

$$
\text { Daily intake of heavy metals }\left(\frac{\mu g}{d a y}\right)=\mathrm{C}_{\mathrm{M}} \times \frac{D C}{B_{a v}}
$$

Where $\mathrm{C}_{\mathrm{M}^{-}}$Concentration of heavy metals in fruits and vegetables, DC - Daily fruit or vegetable consumption and Bav - average body weight

The daily fruit and vegetable consumption was obtained through a formal survey conducted in the study area. An interview of 150 persons of the 25-50 years age group and in the range $55-80 \mathrm{~kg}$ body weight was conducted in the three towns (Mojo, Meki and Zeway) regarding their daily consumption rate of the fruit and vegetables tested.

An average consumption rate of each fruit and vegetable per person per day was calculated from these data.

Flame Atomic Absorption Analysis. Analysis for the heavy metals was performed using atomic absorption spectrometry (Parkin - Elmer Atomic Absorption spectrometer). Measurements were made using standard hollow cathode lamps for $\mathrm{Pb}, \mathrm{Cd}, \mathrm{Zn}, \mathrm{Cu}, \mathrm{Co}$, and $\mathrm{Ni}$. The limit of detection (LOD) of the analytical method for each metal was calculated as being triple the standard deviation of a series of measurements for each solution, the concentration of which is distinctly detectable above the background level. These values were $0.001,0.001,0.001,0.003,0.001$, and 0.002 mg/kg for $\mathrm{Pb}, \mathrm{Cd}, \mathrm{Zn}, \mathrm{Cu}, \mathrm{Co}$, and $\mathrm{Ni}$, respectively. Also, the limit of quantification (LOQ) of the element was determined; these were calculated as $0.003,0.003,0.003$, $0.01,0.003$, and $0.007 \mathrm{mg} / \mathrm{kg}$ for $\mathrm{Pb}, \mathrm{Cd}, \mathrm{Zn}, \mathrm{Cu}, \mathrm{Co}$, and $\mathrm{Ni}$, respectively. The standard operating conditions for the analysis of heavy metals using atomic absorption spectrometry used in our experiments are given in Table 1.

Table 1: Standard operating conditions for the analysis of heavy metals using atomic absorption spectrometry

\begin{tabular}{|c|c|c|c|c|}
\hline Metal & $\begin{array}{c}\text { Wavelength } \\
(\mathrm{nm})\end{array}$ & $\begin{array}{c}\text { Lamp current } \\
(\mathrm{mA})\end{array}$ & Flame & $\begin{array}{c}\text { Slit } \\
\text { width(nm) }\end{array}$ \\
\hline $\mathrm{Pb}$ & 283.312 & 5.0 & Air - acetylene & 0.4 \\
\hline $\mathrm{Cd}$ & 228.860 & 5.0 & Air - acetylene & 0.4 \\
\hline $\mathrm{Cu}$ & 324.830 & 5.0 & Air - acetylene & 0.4 \\
\hline $\mathrm{Zn}$ & 213.920 & 5.0 & Air - acetylene & 0.4 \\
\hline $\mathrm{Co}$ & 240.730 & 5.0 & Air - acetylene & 0.4 \\
\hline $\mathrm{Ni}$ & 232.030 & 5.0 & Air - acetylene & 0.2 \\
\hline
\end{tabular}

\section{Results and Discussion}

The study reports on the heavy metal content of $\mathrm{Pb}, \mathrm{Cd}, \mathrm{Zn}$, $\mathrm{Cu}, \mathrm{Co}$, and $\mathrm{Ni}$ determined in selected fruit and vegetables collected from production farms in the study areas. The observed concentrations of the heavy metals in the fruit and vegetables were compared with the allowed limit as established by the FAO/WHO in 1999 to evaluate the levels of food contamination. The mean concentrations and range of heavy metals found in fresh fruit and vegetables sampled from the study areas, Ethiopia are summarized in Table 2.

Table 2: Concentration of heavy metals (ppm) in fruits and vegetables

\begin{tabular}{|c|c|c|c|c|c|c|}
\hline & \multicolumn{7}{|c|}{ Concentration of Metals(ppm) } \\
\cline { 2 - 7 } & $\mathrm{Pb}$ & $\mathrm{Cd}$ & $\mathrm{Zn}$ & $\mathrm{Cu}$ & $\mathrm{Co}$ & $\mathrm{Ni}$ \\
\hline Grape & $0.22 \pm 0.03$ & $0.04 \pm 0.01$ & $2.33 \pm 0.09$ & $2.13 \pm 0.19$ & $0.21 \pm 0.08$ & $1.42 \pm 0.57$ \\
\hline Watermelon & $0.29 \pm 0.20$ & $0.03 \pm 0.015$ & $2.11 \pm 0.05$ & $1.19 \pm 1.00$ & $0.14 \pm 0.09$ & $0.39 \pm 0.17$ \\
\hline Papaya & $0.17 \pm 0.14$ & $0.06 \pm 0.01$ & $2.84 \pm 0.49$ & $0.93 \pm 0.83$ & $0.08 \pm 0.06$ & $0.74 \pm 0.11$ \\
\hline Strawberry & $0.23 \pm 0.20$ & $0.03 \pm 0.01$ & $1.02 \pm 0.50$ & $3.14 \pm 0.58$ & $0.27 \pm 0.02$ & $1.08 \pm 0.03$ \\
\hline Onion & $0.16 \pm 0.07$ & Nill & $16.4 \pm 0.06$ & $6.38 \pm 0.06$ & $0.58 \pm 0.02$ & $0.37 \pm 0.03$ \\
\hline Tomato & $0.15 \pm 0.06$ & $0.05 \pm 0.02$ & $17.68 \pm 0.63$ & $2.04 \pm 0.05$ & $0.45 \pm 0.01$ & $2.20 \pm 0.05$ \\
\hline Cabbage & $0.21 \pm 0.06$ & $0.03 \pm 0.01$ & $8.43 \pm 0.18$ & $1.66 \pm 0.03$ & $1.23 \pm 0.23$ & $1.05 \pm 0.91$ \\
\hline Carrot & $0.24 \pm 0.05$ & Nill & $13.61 \pm 0.52$ & $5.09 \pm 0.11$ & $1.54 \pm 0.01$ & $1.21 \pm 0.01$ \\
\hline
\end{tabular}

The heavy metal concentrations determined were based on sample dry weight. The results showed that the levels of $\mathrm{Pb}$ in all commodities ranged between $0.14 \mathrm{ppm}$ in tomatoes and $0.31 \mathrm{ppm}$ in watermelon. The Cd content ranged from Nill ppm in carrot and Onion to $0.07 \mathrm{ppm}$ in papaya. Within the selected fruit, the highest concentrations of $\mathrm{Pb}$ were noticed in watermelon whereas in the vegetables studied the highest concentration of $\mathrm{Pb}$ was found in carrot. 
International Journal of Science and Research (IJSR)

ISSN (Online): 2319-7064

Index Copernicus Value (2013): 6.14 | Impact Factor (2015): 6.391

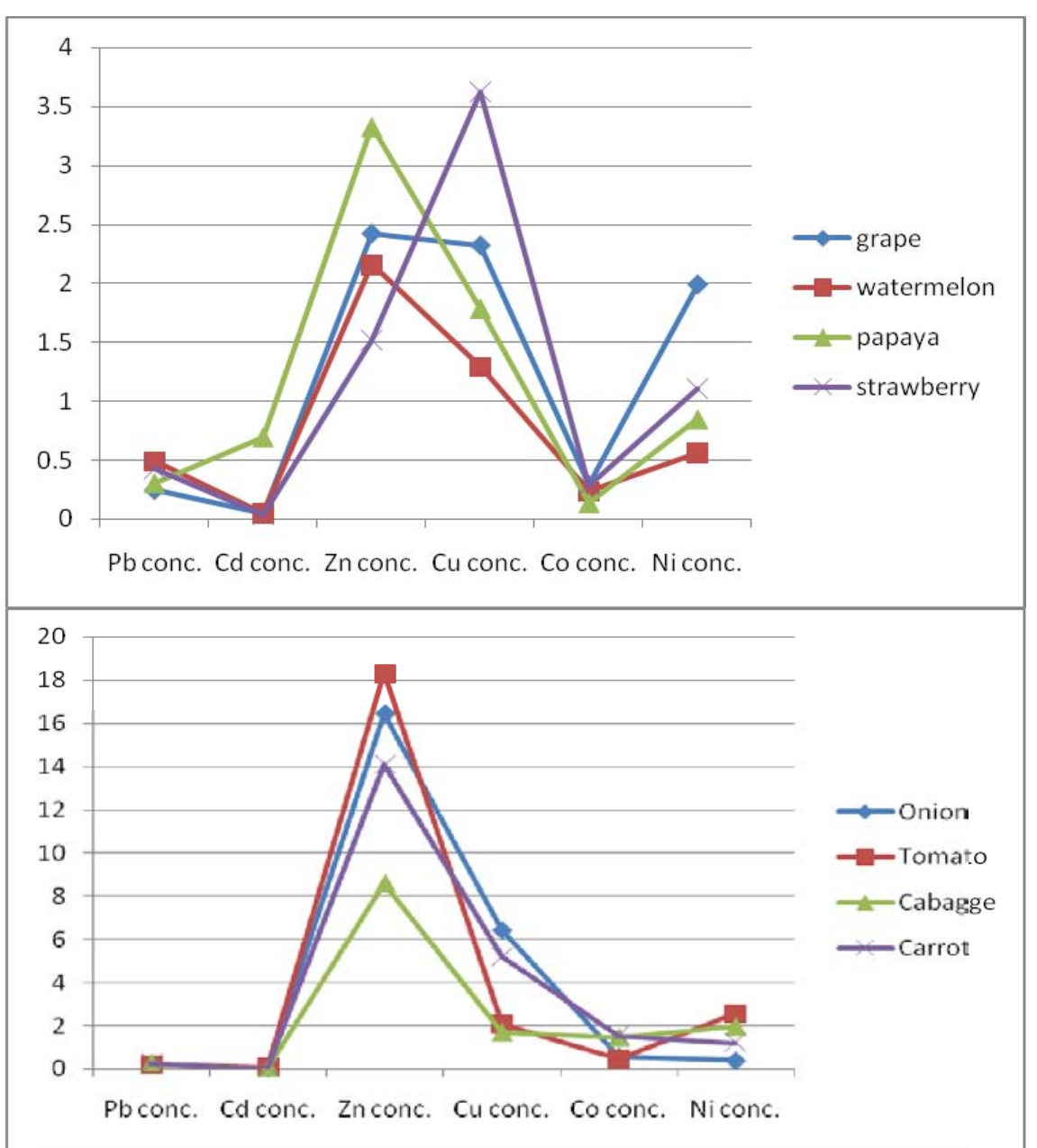

Figure 1: Comparison of heavy metals concentration in fruits and vegetables

In addition to its function as a biocatalyst, $\mathrm{Cu}$ is necessary for body pigmentation, for the maintenance of a healthy central nervous system, and for the prevention of anaemia. $\mathrm{Cu}$ is interrelated with the function of $\mathrm{Zn}$ and $\mathrm{Fe}$ in the body [19 - 21]. The $\mathrm{Cu}$ content ranged from $1.29 \mathrm{ppm}$ in watermelon to $6.44 \mathrm{ppm}$ in onion. Within the selected fruit, the highest concentrations of $\mathrm{Cu}$ were noticed in strawberry whereas in the vegetables studied the highest concentration of $\mathrm{Cu}$ was found in onion. Comparison of heavy metals in fruits and vegetables is described using figure 1.

$\mathrm{Zn}$ is an essential element for plants and animals similar to $\mathrm{Cu}$, but only a small increase in its level may cause interference with physiological processes [19, 20]. The presence of $\mathrm{Zn}$ seems to be essential to neutralize the toxic effects of Cd [22]. In this study, the maximum quantity of zinc was detected in Tomatoes $(17.68 \mathrm{mg} / \mathrm{kg})$ while Strawberries had the lowest concentration $(1.02 \mathrm{mg} / \mathrm{kg})$. Cobalt is an essential element required for the normal functioning of the pancreas, for the formation of cobalamin and it can promotes RBC formation [20, 23]. The maximum quantity of Cobalt was detected in Carrot $(1.54 \mathrm{mg} / \mathrm{kg})$ while papaya had the lowest concentration $(0.08 \mathrm{mg} / \mathrm{kg})$. Nickel has not been recognized as an essential element in humans. At excess level it has toxicity and among the known health related effects of nickel are skin allergies, lung fibrosis, variable degrees of kidney and cardiovascular system poisoning and stimulation of neoplastic transformation [24, 25]. In this study, the maximum quantity of nickel was detected in Tomatoes $(2.20 \mathrm{mg} / \mathrm{kg})$ while the least was detected in watermelon $(0.39 \mathrm{mg} / \mathrm{kg})$.

The exposure of consumers and the related health risks are usually expressed in terms of the provisional tolerable daily intake (PTDI) [17, 18]. The FAO/WHO have set a limit for the heavy metal intake based on body weight for an average adult, namely, $60 \mathrm{~kg}$ body weight. The average diets per person per day of vegetables and fruits obtained by survey from the study areas are 78 and $67 \mathrm{~g}$, respectively. If the mean levels of $\mathrm{Pb}(0.23 \mathrm{mg} / \mathrm{kg}), \mathrm{Cd}(0.04 \mathrm{mg} / \mathrm{kg}), \mathrm{Cu}(1.85$ $\mathrm{mg} / \mathrm{kg}), \quad \mathrm{Zn} \quad(2.07 \mathrm{mg} / \mathrm{kg}), \quad \mathrm{Co} \quad(0.17 \mathrm{mg} / \mathrm{kg})$, and $\mathrm{Ni}$ $(0.91 \mathrm{mg} / \mathrm{kg})$ found here are consumed daily, the contribution of heavy metal intake for an average human being from the fruit diet is $27,5 \mu \mathrm{g}, 4.78 \mu \mathrm{g}, 2.213 \mathrm{mg}, 2.48 \mathrm{mg}, 20.33 \mu \mathrm{g}$, and $1.09 \mathrm{mg}$, respectively. In case of vegetables, if the consumed daily mean levels of $\mathrm{Pb}, \mathrm{Cd}, \mathrm{Zn}, \mathrm{Cu}, \mathrm{Co}$, and $\mathrm{Ni}$ are 0.19 , $0.04,14.03,3.79,0.95$ and $1.21 \mathrm{mg} / \mathrm{kg}$, respectively, the corresponding estimated daily intake will be $26.46 \mu \mathrm{g}$, $5.57 \mu \mathrm{g}, 1.96 \mathrm{mg}, 5.28 \mathrm{mg}, 13.23 \mu \mathrm{g}$, and $0.169 \mathrm{mg}$, respectively. It can therefore be concluded that our estimated daily intakes for the heavy metals studied here are below those reported by the FAO/WHO.

\section{Conclusion}

In conclusion, the results reported here confirm that the fruit and vegetables collected from chosen production area of Ethiopia contained measured heavy metal contents within 


\section{International Journal of Science and Research (IJSR) \\ ISSN (Online): 2319-7064 \\ Index Copernicus Value (2013): 6.14 | Impact Factor (2015): 6.391}

the safe limits prescribed by the WHO in 1999. This is an important result as human health is directly affected by ingestion of fruit and vegetables; the biomonitoring of trace elements in fruit and vegetables needs to be continued because these are the main sources of food for humans.

\section{References}

[1] Ariel, R.V., George, A.M., Gabriel, O.S., Carlos, H.C. (2009). Nutritional Quality of Fruits and Vegetables. Postharvest Handling: A system Approach, 5, 58-93.

[2] Guerra, F., Trevizam, A.R., Muraoka, T., Marcante, N.C., Canniatti-Brazaca, S.G. (2011). Heavy metals in vegetables and potential risk for human health. Sci. Agric. 69(1), 54-60.

[3] Sharma, R., K., Agrawal, M., Marshall, F.M. (2009). Heavy metals in vegetables collected from production and market sites of a tropical urban area of India. Food and Chem. Tox., 47, 583-591.

[4] Rajendran,P., Muthukrishnan, J., Gunasekaran, P. (2003). Microbes in heavy metal remediation. Indian Journal of Expermental Biology, 41, 935 - 944.

[5] Tangahu, B.V., Abdullah, S. R., Basri, H., Idris, M., Anuar, N., Mukhlisin, M. (2011). A Review on Heavy Metals (As, $\mathrm{Pb}$, and $\mathrm{Hg}$ ) Uptake by Plants through Phytoremediation. International Journal of Chemical Engineering.

[6] Martin, S., Griswold, W. (2009). Human health effects of heavy metals. Environmental Science and Technology Briefs for Citizens, 15, Kansas State University.

[7] Hutto, M. (1987). Human health concerns of Lead, Mercury, Cadmium and Arsenic. P. John Wiley and sons Ltd.

[8] Boamponsem, G. A., Kumi, M., Debrah, I. (2012). Heavy Metals Accumulation In Cabbage, Lettuce And Carrot Irrigated With Wastewater From Nagodi Mining Site In Ghana. IJSTR,1, 124-129.

[9] Smical, A., Vasile, H., Oros, V., Jozsef, J., Elena, P. (2008). Studies of Transfer and Bioaccumulation of Heavy Metals from soil into lettuce. Environmental Engineering and Management Journal, 7, 609-615.

[10] Porebska, G., Ostrowska, A. (1999). Heavy Metal Accumulation in Wild Plants: Implications for Phytoremediation. Polish Journal of Environmental Studies, 8(6), 433-442.

[11]Lise, S. P., Erik, H. L., Poul B. L., Preben, B. (2002). Uptake of Trace Elements and PAHs by Fruit and Vegetables from Contaminated Soils. Environ. Sci. Technol., 36, 3057 - 3063.

[12] Sobukola, O.P., Adeniran, O.M., Odedairo, A.A., Kajihausa, O.E. (2010). Heavy metal levels of some fruits and leafy vegetables from selected markets in Lagos, Nigeria. Afr. J. Food Sci., 4(2), 389-393.

[13] Gebregziabher, B., Tesfaye, S. (2014) Assessment of levels of Lead, Cadmium, Copper and Zinc contamination in selected edible vegetables. IJIAS, 7 , $78-86$.

[14] Elbagermi, M. A., Edwards, H. G. M., Alajtal, A. I. (2012). Monitoring of HeavyMetal Content in Fruits and Vegetables Collected from Production and Market Sites in theMisurata Area of Libya. ISRN Analytical Chemistry.
[15] Igwegbe, A. O., Agukwe, C. H., Negbenebor, C. A. (2013). A Survey of Heavy Metal (Lead, Cadmium and Copper) Contents of Selected Fruit and Vegetable Crops from Borno State of Nigeria. 2(1), 1-5.

[16] Kalagbor, I.A., Opusunju, K. (2015). A comparison study of dry and wet ashing methods used for the assessment of concentration of five heavy metals in three vegetables from Rivers State, Nigeria. Int. Res. J. Public Environ. Health, 2(2), 16 -22.

[17] Wang, X., Sato, T., Xing, B., Tao, S. (2005). Health risks of heavy metals to the general public in Tianjin, China via consumption of vegetables and fish. Sci Total Env., 350,28-37.

[18] Orisakwe, O.E., Nduka, J.K., Amadi, C.N., Dike, D.O., Bede, O. (2012). Heavy metals health risk assessment for population via consumption of food crops and fruits in Owarri, South Eastern, Nigeria. Chemistry Central Journal, 6, 77.

[19] Osredkar, J., Sustar, N. (2011). Copper and Zinc, Biological Role and Significance of Copper/Zinc Imbalance, Review. J Clinic Toxicol.

[20] Soetan, K.O., Olaiya, C.O., Oyewola, O.E. (2010). The importance of minerals elements for humans, domestic animals and plants, Review. Afr. J.Food Sci., 4(5), 200 222.

[21] Angelova, M., Asenova, S., Nedkova,V., KolevaKolarova, R. (2011). Copper in the human organism, Review. Trakia Journal of Science, 9(1), 88-98.

[22] Cherif, J., Mediouni,C., Ammar, W.B., Jemal, F. (2011). Interactions of zinc and cadmium toxicity in their effects on growth and in antioxidative systems in tomato plants (Solanum lycopersicum). Journal of Environmental Sciences, 23(5), 837-844.

[23] Radwan, M.A., Salama, A.K. (2006). Market basket survey for some heavy metals in Egyptian fruits and vegetables, Food and Chemical Toxicology, 44, 12731278.

[24] Duda-Chodak,A., Blaszczyk, U. (2008) The impact of nickel on human health, Review. J. Elementol., 13(4), 685-696.

[25] Dankhaus, E., Sanikow, K. (2002). Nickel essentiality, toxicity, and carcinogenity, Critical review in Oncology Hematology, 42(1), 35 - 56. 